\title{
Investigation of the long term effects of chronic white noise stress on learning in radial arm maze and behaviors in forced swim test
}

\author{
Evren ERASLAN-UYGUR, Elif ERGÜL-EKİZ, İbrahim AKYAZI, Güldal İNAL-GÜLTEKİN, \\ Murat ARSLAN
}

Department of Physiology, Faculty of Veterinary Medicine, Istanbul University Istanbul / Turkey.

\begin{abstract}
Summary: The long-term effects of $100 \mathrm{~dB}$ chronic white noise stress (WNS), exposed during prenatal and adolescent periods, on some cognitive functions and behaviors in rats were investigated. For this purpose, 40 female Sprague Dawley rats and their 60 male offspring were used. Pregnant rats were divided into Prenatal Stress (PS) and Prenatal Control (PC) groups. Noise stress was applied to PS group between the 14th and 21st days of their pregnancy, while PC rats were left undisturbed. After weaning, 60 male pups of PS dams were assigned to prenatal + chronic postnatal stress (PSCS), prenatal stress + non stress (PSN) and Control (CON) groups. During the postnatal 30th and 51st days, WNS was applied to PSCS rats, while PSN and CON groups were left undisturbed. The effects of stress on adult male offspring were investigated using 8-arm radial maze and forced swimming tests. There were no significant differences among groups for cognition and behavior tests. These results indicate that chronic $100 \mathrm{~dB}$ WNS does not have log-term effects on cognitive functions and depression related behaviors of adult male offspring.
\end{abstract}

Key words: cognition, forced swim, rats, stress, white noise.

\section{Kronik beyaz gürültü stresinin radyal labirentte öğrenme ve zorunlu yüzme testinde davranışlar üzerine olan uzun dönem etkilerinin araştırılması}

\begin{abstract}
Özet: Çalışmada sıçanlarda prenatal ve adolesan dönemlerde uygulanan kronik, $100 \mathrm{~dB}$ şiddetindeki beyaz gürültü stresinin bazı davranışlar ve kognitif fonksiyonlar üzerine olan uzun dönem etkileri araştırılmıştır. Bu amaçla 40 adet dişi Sprague Dawley sıçan ve bunlardan elde edilen 60 erkek sıçan kullanıldı. Gebe dişiler Prenatal Stres (PS) ve Prenatal Kontrol (PK) grubu olmak üzere iki gruba ayrıldılar. Gebeliğin 14. ve 21. günleri arasında PS grubuna ses stresi uygulanırken, kontrol grubuna herhangi bir uygulama yapılmadı. Yavrular sütten kesildikten sonra PS grubu dişilerden elde edilen 60 adet erkek yavru prenatal stres + kronik postnatal stres (PSKS), prenatal stres + stres uygulanmayan (PSSU) ve Kontrol (KON) gruplarına ayrıldılar. PSKS grubu ratlara postnatal dönemin 30. ve 51. günleri arasında stres uygulaması yapılırken, PS ve KON grubundaki ratlara herhangi bir uygulama yapılmadı. Stresin etkileri erişkin erkek sıçanlarda sekiz kollu radyal labirent testi ve zorlamalı yüzme testi kullanılarak ölçüldü. Kognitif ve davranışsal testler açısından gruplar arasında önemli bir farklılık bulunmadı. Elde edilen sonuçlar kronik, $100 \mathrm{~dB}$ beyaz ses stresinin erişkin erkek sıçanlarda kognitif fonksiyonlar ve depresyonla ilişsili davranışlar üzerinde uzun dönem etkisinin olmadığını göstermektedir.
\end{abstract}

Anahtar sözcükler: beyaz gürültü, kognisyon, rat, stres,zorunlu yüzme.

\section{Introduction}

All human beings and animals are exposed to short or long term stressfull events during their life span. Effects of these stressful experiences on brain, cognition and behaviors and also persistency of these effects in later life depends on the stress regime and nature of the stressor $(2,8,15)$.

Noise is one of the most widespread sources of enviromental stress. With rapid industrialization in modern society, noise has become an important stressor that threatens health of humans and welfare of animals $(6,7,16)$. Although many studies investigated the effects of exposure to different stressors during the prenatal and postnatal periods of life $(3,10,21)$, there are only limited research on the effects of noise stress. It was reported that acute, subacute and chronic white noise stress (WNS) at the intensity of $100 \mathrm{~dB}$ induced plasma corticosterone increasement in rats $(14,23)$. Moreover effects of chronic noise stress on cognition was investigated in a few studies and negative effects of WNS exposure, $100 \mathrm{~dB} / 4 \mathrm{~h}$ per day for 30 days, on learning and memory in rats were reported $(7,14)$. However, to our knowledge, effects of noise stress during prenatal and adolescent periods on cognition in adult rats have not been investigated.

A large body of research indicates that stressfull events may contribute to the development of depression related behaviors $(12,17,24)$. Although, noise is one of 
the most commenly encountered stressors in nowadays, there is only limited research on the effects of noise stress on emotional state and behavioral response of animals. It was reported that acute exposure to inescapable loud tones induced depressogenic effect in rats (4). However, there is a lack of knowledge on the long term effects of noise stressor on behaviors during the different periods of life.

In the present study, long term effects of chronic audiogenic stress exposed during prenatal and adolescent periods were examined in adult male rats at the behavioral levels. Radial arm maze was used to measure cognitive performance and Porsolt swim test was used to assess depression-like behaviors in rats.

\section{Materials and Methods}

Animals and housing: Forty naive adult female (205 \pm 3 g body weight) and 8 naive adult male Sprague Dawley rats $(305 \pm 9 \mathrm{~g}$ body weight) obtained from the Institute for Experimental Medicine of Istanbul University were bred in our laboratory. They were housed with free access to food and water in a temperature controlled room $\left(21 \pm 1^{\circ} \mathrm{C}\right)$ under a $12: 12 \mathrm{~h}$ light-dark cycle (lights on at 7:00 a.m.). Female rats were grouped (4-5 rats per cage) in clear plastic cages $(46 \times 32 \times 14 \mathrm{~cm})$ with wood chip bedding in the presence of a male for 5-6 days until pregnancy. Vaginal smears were examined every morning daily and the day in which the smear was sperm positive was determined as gestational day 0 . Thereafter, pregnant animals were housed individually.

All efforts were made to minimize the number of animals used and their suffering. The Ethic Committee of Istanbul University Veterinary Faculty approved the experimental protocol of the study.

Stress procedures: Pregnant rats were randomly divided into Prenatal Stress (PS, $n=20)$ and Prenatal Control ( $\mathrm{PC}, \mathrm{n}=20)$ groups. PS rats were exposed to 45 min long WNS at the intensity of $100 \mathrm{~dB}$ (decibel-A scale) SPL (sound pressure level) from day 14 to 21 of pregnancy. During this period, stress was applied once a day at random times of the day. The rat cages were arranged to ensure a similar distribution of noise to all the animals. Noise intensity was measured by placing a sound level meter (CEM DT-8820) in the cages at varied locations and calculating the mean value of different readings. Rats in the PC group remained undisturbed.

The offspring were weaned 21 days after birth and only litters consisting of five to ten pups with approximately half females and half males were kept for the study. To minimize litter effects, no more than 2 male offspring from each litter were assigned to each experimental group. Forty male offspring of the PS group were randomly divided into Prenatal Stress + Chronic
Stress (PSCS, $\mathrm{n}=20)$ and Prenatal Stress + Non Stress (PSN, $n=20)$ groups. Twenty male offspring of the PC group were assigned to Control $(\mathrm{CON}, \mathrm{n}=20)$ group. While the same stress procedure was applied to PSCS rats from day 30 to 51 of postnatal period, PSN and CON rats were left undisturbed.

Behavioral testing: The testing period was started when the animals were young adults, at 70 days of age. Ten animals from each PSCS, PSN and CON groups were tested in the 8-arm Radial Arm Maze (RAM) and in the Porsolt Forced Swim Test (FST). All tests were conducted at the same time of the day beginning at 10:00 a.m. The behavior of the rats was videotaped and then analyzed by experienced observers.

Radial Arm Maze (RAM): The apparatus was a custom-made black plexiglas radial arm maze. It consisted of eight identical arms (601 x $12 \mathrm{w}$ x $20 \mathrm{~h} \mathrm{~cm})$ radiating from a circular platform (30 $\mathrm{cm}$ in diameter). Small plastic food cups were located near the end of each arm. The maze was located in a testing room containing many fixed extra-maze visual cues and it was elevated 60 $\mathrm{cm}$ above the floor level.

Rats were food restricted to achieve approximately $85 \%$ of their ad libitum weights, before radial maze training began. Chocolate flavored crisp rice cereal was used as the food reinforcement. Animals were subjected to 3 days of acclimation trials in which they were allowed to explore the maze for a 10 minutes period each day. Food pellets were scattered throughout the maze on the first day and they were confined closer to the food cups on successive days. Following the acclimation sessions, the animals were given one session per day with all arms accessible over a 15 days period. Before each session, all the arms of the maze were baited a $1 / 3$ to $1 / 2$ peace of cereal. The reinforcements were not replaced during the session. An animal was placed in a circular plastic restraining ring $(30 \mathrm{~cm}$ in diameter and 20 $\mathrm{cm}$ high) in the center of the RAM; the ring was lifted after $30 \mathrm{sec}$ allowing the rat to move freely about the maze. A trial ended when one of the following conditions was reached: (1) the animal has visited all eight arms, (2) the animal has made 16 visits, or (3) $10 \mathrm{~min}$. has passed. The rats' performances were evaluated by the total number of errors, the rank of the first error, and the total number of choices to complete the task. Re-entry into an arm previously visited was scored as an error. A choice was defined as the rat traversed two-thirds of the arm length. For the statistical analyses of data, Day 1 was defined as the first day on which at least eight choices were made.

Porsolt Forced Swim Test (FST): A 2 days Porsolt swim test was conducted for assessment of behavioral despair (22). A test was conducted in a plexiglas transparent cylinder $(40 \mathrm{~cm}$ deep, $30 \mathrm{~cm}$ diameter $)$ 
containing water $\left(25 \pm 1{ }^{\circ} \mathrm{C}\right.$ and $15 \mathrm{~cm}$ in depth). Animals were placed individually into the cylinder and allowed to swim for 15 minutes on the first day and for 5 minutes on the second day of the test. Behavior of the rat was scored as immobile, swimming, jumping and diving. Total time spent in these behaviors was calculated for the 5 min test period on each day. Water was cleaned or changed, when necessary, before the next animal was tested. The behavior of the rats was recorded on videotape and further scored by an investigator.

Immobility was defined as floating in the water without struggling and using only small movements to keep the head above water. Swimming was defined as moving limbs in an active manner, more than necessary to keep the head above water. Jumping was defined as lifting up and revealing at least two-thirds of the body length. Diving was defined as totally immersing in water.

Statistical analyses: Performance on the RAM and FST were analyzed with repeated-measures ANOVA, with the groups as the between-subjects factor and the testing days as the within-subjects factor. Data are expressed as mean \pm sem. Differences were considered to be significant if $\mathrm{P}<0.05$.

\section{Results}

Radial Arm Maze Performance: There were no statistically significant differences between the groups on any measure of their performance. However, there was a significant effect of test day for investigated parameters, indicating that learning took place across the 15 days of testing. The main effect of day was significant for total number of errors, $(\mathrm{F}=5.64, \mathrm{P}<0.01)$ (Fig 1), for rank of the first error $(\mathrm{F}=6.87, \mathrm{P}<0.01)$ (Fig 2) and for total number of choices $(\mathrm{F}=4.58, \mathrm{P}<0.01)$ (Fig 3). But there were no significant effect of treatment group $(\mathrm{P}>0.05)$ (Table 1), nor were there any group by day interactions $(\mathrm{P}>0.05)$.

Porsolt Forced Swim Test: The repeated measures ANOVA indicated that the main effect of day was significant for immobility $(\mathrm{F}=14.89, \mathrm{P}<0.01)$, jumping $(\mathrm{F}=5.88, \mathrm{P}<0.05)$ and diving $(\mathrm{F}=13.49, \mathrm{P}<0.01)$. However the effect of treatment was not significant and the interaction between group and testing days was not significant either (Table 2).

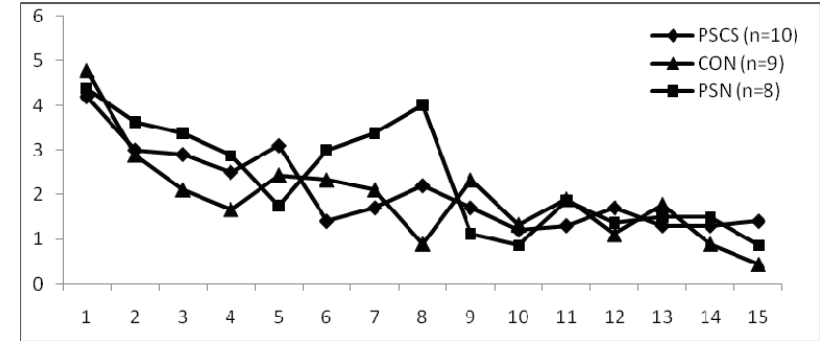

Fig. 1. Total number of errors decreases across testing days $(\mathrm{F}=$ 5.64, $\mathrm{p}\langle 0.001)$ in RAM test. Data are the means for the days of testing for PSCS, PSN and CON groups.

Şekil 1. RAM testinde toplam hata sayısı zamanla azalmaktadır. Veriler PSCS, PSN ve CON gruplarının test günleri ortalamalarını göstermektedir.

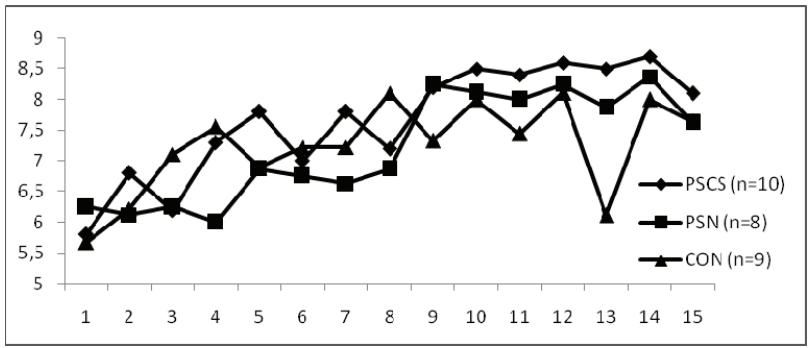

Fig. 2. Rank of the first error increases across testing days $(\mathrm{F}=$ $6.87, \mathrm{p}\langle 0.001)$ in RAM test. Data are the means for the days of testing for PSCS, PSN and CON groups.

Şekil 2. RAM testinde ilk hatanın kademesi zamanla artmaktadır. Veriler PSCS, PSN ve CON gruplarının test günleri ortalamalarını göstermektedir.

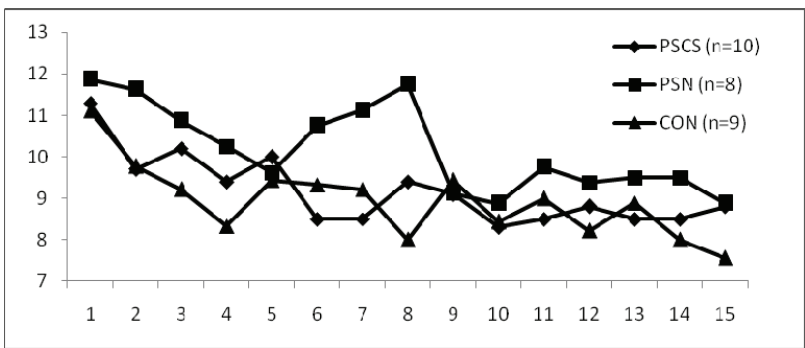

Fig. 3. Total number of choices decreases across testing days $(\mathrm{F}=4.58, \mathrm{p}\langle 0.001)$ in RAM test. Data are the means for the days of testing for PSCS, PSN and CON groups.

Şekil 3. RAM testinde toplam seçim sayısı zamanla azalmaktadır. Veriler PSCS, PSN ve CON gruplarının test günleri ortalamalarını göstermektedir.

Table 1. Parameters measured during RAM test Tablo 1. RAM testinde ölçülen parametreler

\begin{tabular}{lccc}
\hline \multicolumn{1}{c}{ Parameters } & $\begin{array}{c}\text { Treatment Groups } \\
(\mathrm{n}=10)\end{array}$ & $\begin{array}{c}\text { PSN } \\
(\mathrm{n}=8)\end{array}$ & $\begin{array}{c}\text { CON } \\
(\mathrm{n}=9)\end{array}$ \\
\hline Total number of errors & $2.06 \pm 0.46$ & $2.37 \pm 0.51$ & $1.93 \pm 0.48$ \\
Rank of the first error & $7.66 \pm 0.21$ & $7.22 \pm 0.23$ & $7.30 \pm 0.22$ \\
Total number of choices & $9.17 \pm 0.56$ & $10.19 \pm 0.63$ & $8.93 \pm 0.59$ \\
\hline
\end{tabular}

Data are the means \pm SEM. No significant differences were found between groups by repeated measures two-way ANOVA. 
Table 2. Parameters measured during FST

Tablo 2. FST testinde ölçülen parametreler

\begin{tabular}{|c|c|c|c|c|}
\hline \multirow{2}{*}{ Behaviors } & \multirow{2}{*}{ Testing Days } & \multicolumn{3}{|c|}{ Treatment Groups } \\
\hline & & $\operatorname{PSCS}(n=10)$ & $\operatorname{PSN}(n=10)$ & $\mathrm{CON}(\mathrm{n}=9)$ \\
\hline \multirow{2}{*}{ Immobility (sec) } & $1^{\text {st }}$ day & $30.26 \pm 7.86$ & $26.79 \pm 7.86$ & $45.87 \pm 8.29$ \\
\hline & $2^{\text {nd }}$ day & $40.96 \pm 12.83^{*}$ & $48.87 \pm 12.83^{*}$ & $79.05 \pm 13.52 *$ \\
\hline \multirow{2}{*}{ Swimming (sec) } & $1^{\text {st }}$ day & $42.13 \pm 5.96$ & $39.08 \pm 5.96$ & $29.09 \pm 6.28$ \\
\hline & $2^{\text {nd }}$ day & $41.88 \pm 12.48$ & $33.44 \pm 12.48$ & $31.89 \pm 13.15$ \\
\hline \multirow{2}{*}{ Diving } & $1^{\text {st }}$ day & $6.50 \pm 1.42$ & $6.20 \pm 1.42$ & $5.44 \pm 1.49$ \\
\hline & $2^{\text {nd }}$ day & $3.70 \pm 0.90^{*}$ & $1.70 \pm 0.90^{*}$ & $2.56 \pm 0.95^{*}$ \\
\hline \multirow{2}{*}{ Jumping } & $1^{\text {st }}$ day & $18.10 \pm 4.64$ & $23.00 \pm 4.64$ & $26.78 \pm 4.89$ \\
\hline & $2^{\text {nd }}$ day & $10.60 \pm 3.73 *$ & $18.40 \pm 3.73^{*}$ & $16.00 \pm 3.93^{*}$ \\
\hline
\end{tabular}

Data are the means \pm SEM for the days of testing for PSCS, PSN and CON groups. *Immobility $(\mathrm{F}=14.89, \mathrm{P}<0.01)$, jumping $(\mathrm{F}=5.88, \mathrm{P}<0.05)$ and diving $(\mathrm{F}=13.49, \mathrm{P}<0.01)$ behaviors were significantly different on the $2^{\text {nd }}$ day compared to the $1^{\text {st }}$ day of testing. The effect of treatment and group $\mathrm{x}$ trial interactions were not significant.

\section{Discussion}

In the present work, long-term effects of chronic WNS on learning, memory and depressive- like behaviors were investigated.

The white noise has been reported to be an audiogenic stressor that produces stress response in the organism by increasing corticosterone levels and activating different brain areas that are related to formation of stress response $(5,10,23)$. However, to our knowledge, there are only few studies investigating the effects of WNS on learning and memory. Our results show that learning took place across the 15 days of RAM testing (Fig 1, 2 and 3), and that learning and memory of animals in the maze were not affected by prenatal and postnatal chronic WNS treatment (Table 1). It was reported that chronic (4 hours/day x 30 days) white noise $(100 \mathrm{~dB})$ exposure in adult rats impaired spatial learning and memory in Morris water maze when measured from stress application day 26 to 30,2 hours after noise exposure (7). It was also suggested that chronic WNS ( $100 \mathrm{~dB} / 4$ hours per day/30 days) impaired reference and working memories in RAM in adult rats when measured an hour after noise stress exposure during the stress application period (14). Our results are contradictory to these two studies. They measured spatial abilities of animals during the stress application period immediately after the stress exposure. Thus they have focused on the immediate effects of stress exposure on cognition. However our aim was to investigate the lasting consequences of the noise stress exposure. Therefore the lack of effects of WNS on cognition in our study can be accounted for by evaluating the learning performance of animals at adulthood, not immediately after the cessation of stress period. In addition, stress regimes are different i.e. the duration of stress application per day was shorter in our study. There are various studies that have investigated the effects of different types of stressors on learning and memory of rats and they have documented a variety of different results. It was reported that chronic restraint stress, $6 \mathrm{~h} /$ day for 21 days, caused small but significant decrement in performance in RAM, but this cognitive impairment was not permanent. Stressed rats' performance in radial maze returned to normal 18 days after the stress (13). Our results are somewhat comparable to this study. Long-term, persistent effects of chronic stress on cognition were not found in this study either.

In accordance with our results Mello et al (19) did not found any effects of, daily exposure to $5 \mathrm{~min}$ mild foot shock stress for both 2 and 8 weeks on memory acquisition and retention. Moreover, it was also reported that only rats exposed to $6 \mathrm{~h} / 21 \mathrm{~d}$ restraint paradigm showed consistent spatial memory deficits, but the same stress application for $2 \mathrm{~h} / 10 \mathrm{~d}, 2 \mathrm{~h} / 21 \mathrm{~d}$ and $6 \mathrm{~h} / 10 \mathrm{~d}$ did not have any effect on cognition (18). On the other hand, cognitive impairments after chronic stress exposure (1, $20)$ and also negative consequences of stress on learning and memory later in life have been determined $(11,25)$. Discrepancies in results of the studies support the idea that effects of stress on cognition vary depending on the type and intensity of stressors, application period and stress procedure, as well as on the duration from the end of the stress to the start of behavioral assessment. Therefore, we suggest that $100 \mathrm{~dB}$ WNS, which was applied chronically during prenatal and adolescent periods, does not have long term effects on spatial learning and memory performance in adult rats.

There were no statistically significant differences between the groups in the Porsolt forced swim test (Table 2). That is to say, our stress treatment did not affect the depressive like behaviors of rats. To our knowledge, research on the effects of noise stress on behaviors associated with depression is very limited. On the contrary to our results, it has been suggested that increased and decreased durations of loud tones have depressogenic effects in rats in the behavioral despair 
model, based on forced swim test (4). However, the type of noise stressor was different than the white noise used in the present study. Moreover, they measured only acute effects of stress exposure, not long-term effects. Therefore, discrepancies in results may not only be due to type and duration of noise stressor, but may also be a consequence of investigating stress effects in different durations after the end of the stress. Results of other studies, using different stressors rather than noise, vary in terms of effects of stress on behaviors. In accordance with our results, it was reported that physical and emotional stress did not have long-term effects on behaviors of rats measured in FST (21). Furthermore, no effects of prenatal restraint stress on depressive-like behaviors in rats' offspring were found when measured at the age of 6 months. On the other hand, it was reported that chronic foot shock stress and restraint stress had opposite effects, while former increased, later decreased the duration of immobility (an indicator of depressionrelated behavior) in FST (26). Furthermore, depressive like effects of chronic stress and long term consequences were reported $(9,27)$. As it was demonstrated in these studies, the type and the intensity of the stressors used and the stress modality and many other factors may affect the results of stress exposure. The lack of effects of noise stress exposure on depressive-like behaviors may be accounted for the type of stressor used in our study or for by investigating the long term effects of stress rather than immediate effects.

As a conclusion it is suggested that chronic WNS $(100 \mathrm{~dB})$ exposed during prenatal and adolescent periods does not have long term effects on cognition and depressive like behaviors of adult rats. Further research is needed to understand the consequences of noise stress exposure and response mechanisms of organism.

\section{Acknowledgements}

This work was supported by Research Fund of Istanbul University (Project number: 207/29042004). The authors sincerely thank Dr. Bülent Ekiz for his valuable contributions to statistical analyses.

\section{References}

1. Abidin I, Yargiçoglu P, Agar A, Gümüslü S, Aydin S, Oztürk O, Sahin E (2004): The effect of chronic restraint stress on spatial learning and memory: relation to oxidant stress. Int J Neurosci, 114, 683-99.

2. Aguilera G (1998): Corticotrophin Releasing Hormone, Receptor Regulation and the Stress Response. Trends Endocrinol Metab, 9, 329-336.

3. Bowman RE (2005): Stress induced changes in spatial memory are sexually differentiated and vary across the lifespan. J Neuroendocrinol, 17, 526-535.

4. Bulduk S, Canbeyli R (2004): Effect of inescapable tones on behavioral despair in Wistar rats. Prog Neuropsychopharmacol Biol Psychiatry, 28, 471-475.
5. Campeau S, Dolan D, Akil H, Watson SJ (2002): c-fos $m R N A$ induction in acute and chronic audiogenic stress: possible role of the orbitofrontal cortex in habituation. Stress, 5, 121-130.

6. Coppola CL, Enns RM, Grandin T (2006): Noise in the animal shelter environment: building design and the effects of daily noise exposure. J Appl Anim Welf Sci, 9, $1-7$.

7. Cui B, Wu M, She X (2009): Effects of Chronic Noise Exposure on Spatial Learning and Memory of Rats in Relation to Neurotransmitters and NMDAR2B Alteration in the Hippocampus. J Occup Health, 51, 152-158.

8. Dal-Zotto S, Martí O, Armario A (2000): Influence of single or repeated experience of rats with forced swimming on behavioural and physiological responses to the stressor. Behav Brain Res, 114, 175-181.

9. Darnaudéry M, Dutriez I, Viltart O, Morley-Fletcher S, Maccari S (2004): Stress during gestation induces lasting effects on emotional reactivity of the dam rat. Behav Brain Res, 153, 211-216.

10. Dayas CV, Buller KM, Crane JW, Xu Y, Day TA (2001): Stressor categorization: acute physical and psychological stressors elicit distinctive recruitment patterns in the amygdala and in medullary noradrenergic cell groups. Eur J Neurosci, 14, 1143-1152.

11. Isgor C, Kabbaj M, Akil H, Watson SJ (2004): Delayed effects of chronic variable stress during peripubertaljuvenile period on hippocampal morphology and on cognitive and stress axis functions in rats. Hippocampus, 14, 636-648.

12. Kendler KS, Karkowski LM, Prescott CA (1999): Causal relationship between stressful life events and the onset of major depression. Am J Psychiatry, 156, 837-841.

13. Luine V, Villegas M, Martinez C, McEwen BS (1994): Repeated stress causes reversible impairments of spatial memory performance. Brain Res, 639, 167-170.

14. Manikandan S, Padma MK, Srikumar R, Jeya Parthasarathy N, Muthuvel A, Sheela Devi R (2006): Effects of chronic noise stress on spatial memory of rats in relation to neuronal dendritic alteration and free radicalimbalance in hippocampus and medial prefrontal cortex. Neurosci Lett, 399, 17-22.

15. Marin MT, Cruz FC, Planeta CS (2007): Chronic restraint or variable stresses differently affect the behavior, corticosterone secretion and body weight in rats. Physiol Behav, 90, 29-35.

16. Marjut MA, Wallenius A (2004): The interaction of noise stress and personal project stress on subjective health. J Environ Psychol, 24, 167-177.

17. McEwen BS (2000): The neurobiology of stress: from serendipity to clinical relevance. Brain Res, 886, 172-189.

18. McLaughlin KJ, Gomez JL, Baran SE, Conrad CD (2007): The effects of chronic stress on hippocampal morphology and function: an evaluation of chronic restraint paradigms. Brain Res, 1161, 56-64.

19. Mello PB, Benetti F, Cammarota M, Izquierdo I (2008): Effects of acute and chronic physical exercise and stress on different types of memory in rats. An Acad Bras Cienc, 80, 301-309.

20. Park CR, Campbell AM, Diamond DM (2001): Chronic psychosocial stress impairs learning and memory and increases sensitivity to yohimbine in adult rats. Biol Psychiatry, 50, 994-1004. 
21. Pijlman FT, Herremans AH, van de Kieft J, Kruse CG, van Ree JM (2003): Behavioural changes after different stress paradigms: prepulse inhibition increased after physical, but not emotional stress. Eur Neuropsychopharmacol, 13, 369-380.

22. Porsolt RD, Anton G, Blavet N, Jalfre M (1978): Behavioural despair in rats: a new model sensitive to antidepressant treatments. Eur J Pharmacol, 47, 379-391.

23. Samson J, Sheeladevi R, Ravindran R, Senthilvelan M (2007): Stress response in rat brain after different durations of noise exposure. Neurosci Res, 7, 143-147.

24. Smith JW, Seckl JR, Evans AT, Costall B, Smythe JW (2004): Gestational stress induces post-partum depressionlike behaviour and alters maternal care in rats. Psychoneuroendocrinology, 29, 227-244.

25. Sterlemann V, Rammes G, Wolf M, Liebl C, Ganea K, Müller MB, Schmidt MV (2010): Chronic social stress during adolescence induces cognitive impairment in aged mice. Hippocampus, 20, 540-549.
26. Swiergiel AH, Zhou Y, Dunn AJ (2007): Effects of chronic footshock, restraint and corticotropin-releasing factor on freezing, ultrasonic vocalization and forced swim behavior in rats. Behav Brain Res, 183, 178-187.

27. Veena J, Srikumar BN, Raju TR, Shankaranarayana Rao BS (2009): Exposure to enriched environment restores the survival and differentiation of new born cells in the hippocampus and ameliorates depressive symptoms in chronically stressed rats. Neurosci Lett, 455, 178-182.

Geliş tarihi: 24.09.2010 / Kabul tarihi: 25.01.20111

\section{Address for correspondance:}

Dr. Evren Eraslan-Uygur

Istanbul University, Faculty of Veterinary Medicine,

Department of Physiology

34320, Avcilar/Istanbul/Turkey

e-mail address: erarslan@istanbul.edu.tr 